\title{
Takotsubo syndrome spreads its tentacles to congenital heart disease
}

\author{
Ibrahim Abdullah, MD
}

\footnotetext{
From Banner Children's Cardon Children's Medical Center, Mesa, Ariz.

Disclosures: Author has nothing to disclose with regard to commercial support.

Received for publication Sept 2, 2017; accepted for publication Sept 8, 2017; available ahead of print Oct 18, 2017.

Address for reprints: Ibrahim Abdullah, MD, Banner Children's Medical Group, 1432 S Dobson Rd, Suite \#512, Mesa, AZ (E-mail: iabdullah1234@gmail.com).

J Thorac Cardiovasc Surg 2017; 154:e111

$0022-5223 / \$ 36.00$

Copyright (C) 2017 Published by Elsevier Inc. on behalf of The American Association for Thoracic Surgery

https://doi.org/10.1016/j.jtcvs.2017.09.025
}

In this issue of the Journal, Oreto and colleagues ${ }^{1}$ describe a case report of an adult female with a diagnosis of pulmonary atresia with a ventricular septal defect (VSD) who had undergone a series of unifocalization procedures earlier in life, followed by a VSD repair, pulmonary homograft placement, and an ascending aortic replacement. Interestingly, this patient underwent closure of her VSD rather late, at the age of 35 years. She represents the first reported patient with the specific diagnosis to present with the rather obscure Takotsubo syndrome (TS).

Oreto and colleagues ${ }^{1}$ aptly depict the 7 recent criteria for TS by the European Cardiology Society. ${ }^{2}$ The syndrome consists of wall motion abnormalities, often triggered by emotional stress but without any evident coronary disease. Furthermore, there is usually complete resolution of left ventricular function with time. A recent retrospective analysis of 6470 critically ill patients admitted to the intensive care unit (ICU) in Sweden from 2012 to 2015, however, showed that 467 had left ventricular dysfunction, among whom 59 fulfilled TS criteria. ${ }^{3}$ Although these were all patients who were initially in hemodynamically unstable condition, the patients with TS were noted to use more ICU resources, have longer ICU stays, and have higher mortality than the ICU patients without TS. For a condition that seems transient in nature, these are certainly noteworthy and concerning findings.

It is interesting that this current report represents the fourth reported case of TS in adult congenital heart disease, with the first case being reported as recently as 2016. This

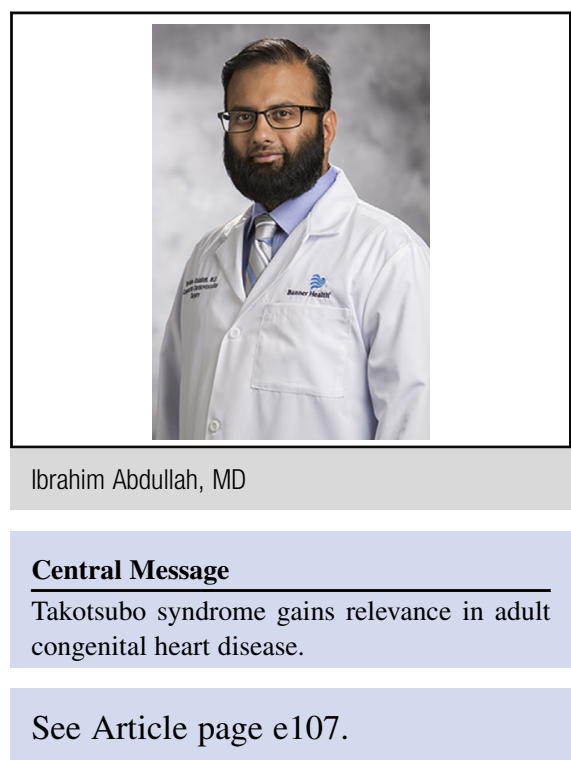

may be a consequence of the emerging adult congenital cardiac population as survival increases, but it also may represent significant underreporting of TS in this population. The adult congenital cardiac population may represent a unique group perhaps more prone to TS because of longstanding myocardial exposure to either cyanosis or overcirculation-both of which may have been present in this patient, who had a VSD for 35 years.

\section{References}

1. Oreto L, Parrella C, Ricci R, Chinali M. The unexpected in grown-up congenital heart disease: Takotsubo syndrome. J Thorac Cardiovasc Surg. 2017; 154: e107-9.

2. Lyon AR, Bossone E, Schneider B, Sechtem U, Citro R, Underwood SR, et al. Current state of knowledge on Takotsubo syndrome: a position statement from the Taskforce on Takotsubo Syndrome of the Heart Failure Association of the European Society of Cardiology. Eur J Heart Fail. 2016;18:8-27.

3. Oras J, Lundgren J, Redfors B, Brandin D, Omerovic E, Seeman-Lodding H, et al. Takotsubo syndrome in hemodynamically unstable patients admitted to the intensive care unit-a retrospective study. Acta Anaesthesiol Scand. 2017; 61:914-24. 